\title{
小動物臨床に特けるクスリの使い方 (XV)
}

5. 抗寄生虫薬の基礎知識（その 4)

荒川皓*

\section{4. 抗 寄 生 虫薬}

\section{5) 抗犬糸状虫薬}

小動物に扣ける抗線虫薬, ことに抗犬系状虫薬は表 5 に示したと拈りである.

Arsenamide sodium: Thiacetarsamide や Caparsolate とも呼ばれる.これは約 $20 \%$ の砒素を含む有機 砒素化合物である. $1 \mathrm{ml}$ 中に $10 \mathrm{mg}$ の有効物質を含む 1\% 溶液として製剤がつくられている，有効物質である 砒素は, イヌの肝を除き, 寄生虫体内での濃度が, 宿主 組織内濃度より高くなる，成虫は，特異的に吪素を摂取 する. このため，イヌ糸状虫の成虫にの及効果があり， 感染子虫や循環血中のミクロフィラリアには効果がな い. 成虫に対する効果は迅速にあらわれるものでなく， 1 部の成虫は投薬後 $1 \sim 2$ 日で殺減されるが, 完全に殺 すには $2 \sim 3$ 週間を必要とする.

本薬による治療が原因であらわれる副作用には $2 つ の$ タイプがある１つは肺動脈内に死んだ成虫が栓塞する ことによって起こる肺の障害と, 1つは砒素による毒性と して腎と肝の両方またはいずれかが受ける障害である. 前者による障害の度合は, 感染の度合とほぼ比例する。 死体の栓塞は血流を阻害し, 激しい炎症を誘発し, とき に細菌の 2 次感染を併発するので肺の機能を著しく減退 させる，咳と発熱がしばしば起こる．たいていの場合， これらの症状を軽減するための療法があるが, アスピリ
ン 3〜 $5 \mathrm{mg} / \mathrm{kg}$ および抗生物質を連日投与し, かつプレ ドニゾロン $1.0 \mathrm{mg} / \mathrm{kg}$ を隔日に投与すると，6〜8 週内 に症状の著しい改善がみられる．少なくとも2 週間は安 静が必要で, 1〜2力月間はイヌの症状を注意深くみてい る必要がある. 一般に䂣素による副作用は現れ難いが， 成虫感染の度合によっては治療後に腎や肝の障害があ る.徵候は速くて治療後 8 時間以内に起こることがある. 治療後 $1 \sim 2$ 時間後に嘔吐がはじまり, 続いて沈うつ, 食欲減退, 高濃度の尿中ビリルビン, 血中ビリルビン増 加による黄㾝の徵候, 肝障害に原因する血中酵素の上昇, BUN の上昇などがある. 成虫駆除に $0.38 \mathrm{mg}$ (As) $/ \mathrm{kg}$ を2 日連続静脈内注射するわけであるが，最初の注射後 に上記のような症状がでた場合は，2回目の注射は中止 すべきである，多量のミクロフィラリアが循環血中にい るとき，吪素剤を用いると肝障害をもたらすことがある ので, ヨウ化ジチアザニンまたはレバミゾールでミクロ フィラリアを殺隇したあとに砒素剂を用いる方がよい。 この場合, ヨウ化ジチアザニン使用後 3 週間をおいてか ら，レバミゾール使用後ならば 6 週間ののちに, 砒素剤 を用いて成虫を殺隇するとよい. 砒素剤投与後， 6〜 12 週後に未だ血中にミクロフィラリアがいるときは, 再度 殺ミクロフィラリアの治療を行らべきである.

砒素剤は感染子虫に効力をもっていないので, 蚊のシ ーズン中に感染した幼虫がすべて成虫になるのを待って 吪素剤を用いるとよい.このような場合は，ヨウ化ジチ

表 5 小動物に拈ける抗線虫薬（抗犬系状虫薬）

\begin{tabular}{|c|c|c|c|c|c|c|}
\hline 薬 & 物 & 名 & 量 - 用 & 成 虫 & ミクロフィラリア & 感染子虫 \\
\hline \multicolumn{3}{|c|}{ Arenamide sodium } & $0.38 \mathrm{mg}(\mathrm{As}) / \mathrm{kg}, 2$ 回 $/$ 日, 2 日, IV & + & & \\
\hline \multicolumn{3}{|c|}{ Diethylcarbamazine* } & $5.5 \mathrm{mg} / \mathrm{kg} /$ 日，連日投与，PO & & & + \\
\hline \multicolumn{3}{|c|}{ Dithiazanine iodide* } & $5 \mathrm{mg} / \mathrm{kg} /$ 日, $.7 \sim 9$ 日, $P O$ & & + & \\
\hline \multicolumn{3}{|c|}{ Ivermectin } & $3 \sim 6 \mu \mathrm{g} / \mathrm{kg}, 30 \sim 60$ 日に 1 回, PO & & + & + \\
\hline \multicolumn{3}{|c|}{ Levamisole $\mathrm{HCl} *$} & $\left\{\begin{array}{l}2.5 \mathrm{mg} / \mathrm{kg} / \text { 日，連日投与，PO } \\
11 \mathrm{mg} / \mathrm{kg} / \text { 日，10日, PO }\end{array}\right.$ & $\left\{\begin{array}{l}+(\text { 雄 }) \\
-(\text { 雌) }\end{array}\right.$ & & + \\
\hline \multicolumn{3}{|c|}{ Melarsonyl pottasium* } & $5.8 \mathrm{mg} / \mathrm{kg}, 2$ 日, $\mathrm{IM}$ & + & & \\
\hline \multicolumn{3}{|c|}{ Milbemycin D } & $1.0 \mathrm{mg} / \mathrm{kg}, 30 \sim 60$ 日に 1 回, $P O$ & & & + \\
\hline \multicolumn{3}{|c|}{ Stibophen* } & $1 \mathrm{mg}(\mathrm{Sb}) / \mathrm{kg} /$ 日， 6 日, INJ & & + & \\
\hline
\end{tabular}

注）十: 有効 *: 動物用医薬品で, イヌ・ネコの抗犬系状虫薬としてわが国で使用許可のあるもの $\mathrm{PO}$ : 経口投与 IM : 筋肉内注射 INJ : 静脈, 筋肉, 皮下注射

* 大阪府立大学農学部 (大阪府堺市百舌鳥梅町 4-804) 
技術

アザニンまたはレバミゾールの殺ミクロフィラリア殽を 春まで毎月投与し，そして䂤素剂を用いる. 成虫駆除の あと, もし血中にミクロフィラリアが存在すれば, 殺ミク ロフィラリア剂を用い, そののちジェチルカルバマジン の予防投与に持って行くべきである. 投与量は砒素実量 $0.38 \mathrm{mg} / \mathrm{kg}$ を 1 回量とし，6時間間隔をおいて 1 日 2 回， 2 日間連続静脈内注射する. 静脈外に薬液を漏らすと激 痛を起こし周辺の組織に激しい炎症を引き起こす.これ を防ぐ方法の 1 つして，4回の注射を異なった個所で 行うことである.もし漏れた場合は冷して圧迫するか, $1 \%$ の塩酸プロカインを $1 \sim 2 \mathrm{ml}$ 局所に注射するとよい. プロカインの注射は疼痛をなくし血管の収縮を抑制する ので組織の壊死を防止する.

Diethylcarbamazine (DEC): DEC は, 感染子虫に 著効があり, 宿主体内に入った幼虫が心蔵へ移行するま えに殺滅し, 成虫の感染を予防する, 循環血中にミクロ フィラリアのいないイヌに対しては毒性はない.しかし イヌにより投与後に嘔吐がみられることがある. 飭を与 えた直後に投薬することによって嘔吐を防ぐこともでき る. 循環血中にミクロフィラリアを持つイヌに投与する と, 嘔吐, 下痢, 虚脱, 呼吸困難, ときに激しいショ ック様症状を起こし死に至らすことがある. この副作用 は DEC の影響を受けたミクロフィラリアが放出する抗 原物質によるアレルギー反応であるといわれる. したが って DEC を与える前にミクロフィラリアを検査し，も し存在すれば, レバミゾールまたはヨウ化ジチアザニン を投与して，その 2 週後に再検查し，ミクロフィラリア のいないことを確認してから，DEC を与えることであ る. 投与量は $5.5 \mathrm{mg} / \mathrm{kg}$ を日量とし, 蚊のシーズンの少 なくとも 2 カ月まえから蚊のシーズン終了 2 カ月まで与 える.ところによっては 1 年中 DEC を投薬する必要が ある. DEC の欠点は, 長期間投与し続けなければなら ない点である.嘔吐が最もよくみられる副作用であるが, 慨を与えた直後に投薬し胃粘膜への刺激を軽減するとよ い. 製剂にはサイポール®錠 (動物専用), 動物用サイポ 一ル®散（いずれも田辺製薬）がある. 前者は 1 錠中に $\mathrm{DEC}$ を $50 \mathrm{mg}$, 後者は散 $1 \mathrm{mg}$ 中に DEC を $5.5 \mathrm{mg}$ 含 有している.またフィラリビッツ(ノールデン, 日本全薬) の錠剤は $60 \mathrm{mg}$ 錠と $180 \mathrm{mg}$ 錠である. 通常 1 日 1 回 体重 $1 \mathrm{~kg}$ 当たり $5.5 \mathrm{mg}$ を連日経口投与する. 使用上 の注意として，(1) 血中にミクロフィラリアがいるイヌ に投与すると重篤なショック症状を起こすことがあるの で，投与前は必ず血液検查を行い集虫法でミクロフィラ リアのいないことを確認してから投薬を開始すること. また, 系状虫に感染した犬に投与する場合には,成虫およ びミクロフィラリアを駆除し, 集虫法でミクロフィラリ アが消失したことを確認してから投薬することである.

(2) 本剤の投与により食欲不振や嘔吐が起こることがあ
講座

る.

Dithiazanine iodide: ヨウ化ジチアザニンは循環血 中のミクロフィラリアに効果があるが, 完全に血中から 消隇しているかどうかは投薬 2 週後に再検査して確かめ る必要がある. もし存在すれば，もら一度本薬を投薬す ベきであるが，その 2 週後に未だミクロフィラリアが認 められるなら，他の薬剤たとえばレバミゾールを投与す ることが必要であろう. 副作用として嘔吐と下痢があ る.これは畜主に十分に警告することが必要で, 家具や 床を污すことがあるからである.この嘔吐・下痢は慨と 同時に，またはその直後に投薬することにより避けるこ とができる. もしヨウ化ジチアザニンを，吪素剤による 成虫駆除のあとに用いるならば, 砒素剤のあと6 週間の 期間をあけることが必要である。 もし砒素剤による治療 中に副作用が現われたならば， 12 週間をあける必要が ある. 成虫駆除のまえにミクロフィラリアを駆除してお く方が砒素剤の副作用は少ない. ミクロフィラリアの駆 除には，4.4〜 $6.6 \mathrm{mg} / \mathrm{kg}$ で 7 日間連続投与する. 最終 投薬の 12 週後に血中のミクロフィラリアを検查し, 必 要なら再度駆除を行う。

製剤にはミコクロリーナ®(佐藤製薬）がある. 1 錠中 にヨウ化ジチアザニン $25 \mathrm{mg}$ を含有し, 殺ミクロフィラ リアとして体重 $5 \mathrm{~kg}$ 当たり 1 錠を日量として, 1 日 $1 〜 2$ 回空腹時に投与する. ミクロフィラリアが消失するまで 3〜10 日（普通 7〜9 日）間投薬する. 使用上の注意として, (1) 肝の機能障害などの重い症状のある場合は回復後に 投薬して，ミクロフィラリアを駆除する. (2) 腸溶錠であ るため, 砕いて投与してはならない. (3) 投薬中または終 了後に 2 3 日間青い便が排出されるが，異常ではない.

Ivermectin：イヌの糸状虫感染の予防に著効があり， 宿主体内に入った幼虫が心蔵に移行するまえに殺隇す る. 1 カ月齢の幼虫に対しては $3 \mu \mathrm{g} / \mathrm{kg}$ 以上の投与量 1 回経口投薬で効果がある. 2 カ月齢の幼虫に対しては 5 $\mu \mathrm{g} / \mathrm{kg}$ 以上で $100 \% ， 3$ 力月龄の幼虫でも $50 \mu \mathrm{g} / \mathrm{kg}$ を投 与すれば部分的ではあるが効果がある. 成虫には効果は ない. ミクロフィラリアに対しては $50 \sim 100 \mu \mathrm{g} / \mathrm{kg} 1$ 回 投与で, 部分的に効果があるとされている. イヌに推定 有効量の 160 倍を 90 日間連続経口投与しても, 諸検査 でまったく異常がみられていないので,きわめて安全性 の高い薬物である. 常用投与量は 3〜 $6 \mu \mathrm{g} / \mathrm{kg}$ を 30 日ま たは 60 日に 1 回投与するだけで，感染予防する.

Levamisole HGl：レバミゾールは感染子虫および循 環血中のミクロフィラリアに対して効果がある. ミクロ フィラリアを殺隇するために $11 \mathrm{mg} / \mathrm{kg}$ を日量とし10日 間連続用いた実験で，イヌの 70〜100\%から完全にミク ロフィラリアが消隇している. 成虫の殺滅のために一連 の砒素の投与が終わってから $3 \sim 6$ 週後に殺ミクロフィ ラリアの目的で用いる. 成虫に対しても毒性があり, 雄 
技術

の成虫に対しては殺虫的に作用するが，雌の成虫に対し てはほとんど毒性がない，成虫に感染していないか，感 染していても軽度か中程度であるイヌに対しては，レバ ミゾールの毒性はあまり問題ではない，毒性は，普通初 めて投薬したあとに起こる. 投薬を中止すると, 大体 2 〜 3 日で回復する. そして再び投薬を開始することがで きる. 症状は括もに, 唾液過多, 筋肉のけいれん, 嘔 吐，ときに運動失調がある. 成虫に大量感染しているイ ヌでは，レバミゾールの毒性に対する症状は激しいこと が多く，ときに死を招く、このよらなイヌに対しては，

日量 $2.5 \mathrm{mg} / \mathrm{kg}$ を 7 日, 日量 $5 \mathrm{mg} / \mathrm{kg}$ を 7 日, 日量 10 $\mathrm{mg} / \mathrm{kg}$ を 7 日， $10 \mathrm{mg} / \mathrm{kg}$ を日に 2 回 14 日間投薬のよう に, 徐々に投薬量を増加して成虫を駆除することができ る.このよらに成虫，ことに雄およびミクロフィラリア を殺隇するが，ミクロフィラリアのみを殺滅するのもよ い.もし成虫が生存していても，ミクロフィラリアを殺 滅しておけば，以後は感染予防のために DEC を予防薬 として用いることができる. この点はヨウ化ジチアザニ ンの用い方と同じである. いずれの場合も生存する成虫 の病害が進行することがあるため，注意を必要とする．

わが国で用いられる製剤にはピカシン錠（ヤンセン， 共立商事）がある.これは 1 錠中に塩酸レバミゾールを $10 \mathrm{mg}$ 含有する. 系状虫の感染予防として 1 日 1 回体重 $4 \mathrm{~kg}$ 当たり 1 錠を連日または隔日経口投与する. 使用上 の注意として, (1) 体重 $4 \mathrm{~kg}$ 未満のイヌに使用しない こと, (2) ビーグル犬で溶血性貧血を起こしたとの報告 がある，(3) 獣医師の診断により使用すること, (4)一 時的に軽度の食欲不振および軟便, 一過性の嘔吐を起こ すことがある. また，間欠的集中投与法 $(15 \mathrm{mg} / \mathrm{kg} /$ 日 を3 回に分けて，5 日間投与を 1 クールとして，感染開 始から約 2 カ月半頃に投与し, さらに 2 カ月後に 1 クー ル投与）も確実な予防効果のあることが認められている.

Melarsonyl pottasium: これは成虫に対する駆除剂 で，砒素を含む化合物である，製剤にはトリメラルサン (ローヌ・プーラン, 共立商事)がある. この薬物は既述 のアルゼナミド・ナトリウムにくらべ毒性が低く, 組織 侵襲性が少ないのが特長である. 1 バイアル中にメラル ソニル・カリウムが $233 \mathrm{mg}$ 入って拈り，これを $2 \mathrm{ml}$ の溶解液に溶かす．これを，体重 $1 \mathrm{~kg}$ 当たり $0.05 \mathrm{ml}$ を2 日間連続して筋肉内に注射する. 注射部位に腫脹, 浮腫, 硬結, 疼痛などを起こすことがあるので, 使用量 の多いときは 2 カ所に分けて注射するとよい. 静脈内注 射法としては, (1) $5 \mathrm{mg} / \mathrm{kg}$ を〜 8時間間隔で計 4 回 注射し, 総量 $20 \mathrm{mg} / \mathrm{kg}$ とする方法. また, (2) $5 \mathrm{mg} / \mathrm{kg}$ を初回, 2 回目から $2.5 \mathrm{mg} / \mathrm{kg}$ を 12 時間間隔で計 4 回注射し, 総量を $12.5 \mathrm{mg} / \mathrm{kg}$ とする方法もある. い ずれの場合も，本剤は溶解後ただちに使用することであ る. 肝や腎に重度の障害を有するイヌには使用しないこ
講座

と. 駆除された成虫は肺動脈で栓塞を起こすことがある ので, 投与後 $2 \sim 3$ 週間は管理に十分に注意し, 必ず運 動は制限すること. 本剤はジメルカプロールやグルタチ オン等の解毒剤と使用しないこと.V.C.S. のイヌには 成虫駆除は禁物である. 肺動脈への栓塞症状を出すイヌ に対する療法はアルゼナミド・ナトリウムのそれと同じ である。

Milbemycin D：新しい抗生物質性のフィラリア予防 薬で, 既述のアイベルメクチンと同じ系統に属する. $1.0 \mathrm{mg} / \mathrm{kg}$ を 1 回量とし，月 1 回または 2 カ月に 1 回投 薬するだけで，幼虫が成虫になるのを完全に予防すると 報告されている。

Stibophen: Fuadin とも呼ばれている. これはアン チモン剂で, ピトやィヌのフィラリア感染の治療に用い られている. 特長は流血中のミクロフィラリアに対して 効果をもつ点である. 白い結晶で水に容易に溶け, $\mathrm{pH}$ 7.3 で $6.3 \%$ 溶液が製剤である. 投薬方法は筋肉内, 静 脈内，皮下の注射である. 投薬した薬物の半分は腎から 排泄され，胆汁を介しても排泄される．他は甲状腺, 肝, 脾や他の器官に貯蔵され徐々に排泄される. このアンチ モン剤は雌成虫の卵巣に壊死を起こし不妊にし, ミク口 フィラリアの産生を停止させ，また徐々に成虫をむ殺隇 する. このため, 死隇した成虫が肺動脈や心臓に栓塞を 起こす危険が少ないという点が特色である. 一般状態の 悪いイヌに用いることは避けるべきで, 状態が改善され てから投薬すべきである. アンチモンが心臓よりも肺， 肝，腎に残留しやすいために肝・腎障害があらわれやす い. 肝小葉の壊死や腎炎を誘発するので, 治療開始前に 肝・腎機能を検查しておくことが必要である.

わが国で許可されている製剤はファジン®(バイェル， 日本特殊農薬) である. 製剤 $1 \mathrm{~m} l$ にスチボフェンを 63 $\mathrm{mg}$ 含む注射用の製剤である.イヌのミクロフィラリ アのほか馬のセタリアの血中子虫を駆除するのに用い る.イヌに静脈内または皮下注射する場合, 隔日に体重 $20 \mathrm{~kg}$ 当たり初回量として $2.4 \mathrm{ml}$ (アンチモン実量 $1 \mathrm{mg}$ $/ \mathrm{kg})$ より始め, $3.5 \mathrm{ml}$ まで漸増して投与する.ただし， 総量として $15.8 \mathrm{ml}$ を超えないこと. 筋肉内注射の場合 は, 体重 $20 \mathrm{~kg}$ 当たり第 1 週目には $2.4 \mathrm{ml}$ (アンチモ ン実量 $1 \mathrm{mg} / \mathrm{kg}$ )を 6 日間連続投与し， 1 日休薬ののち 第 2 週目には $2.8 \mathrm{ml}$ を 6 日間連続投与する. ただし, ミクロフィラリアの消失が不完全であった時は, 1 週間 休薬し, 同様の処置を繰り返すこと. 使用上の注意とし ては，(1) 肝・腎等に重度の障害を有する動物には使用 しない. (2) 妊娠末期の動物には極力使用を避ける. (3) 発熱, 強直, 浮腫, 筋肉痛, 嘔吐, 下痢, 食欲不振, 角・結膜炎を起こすことがあるので，これらの症状のあ らわれた場合にはただちに使用を中止する,などである.

(つづく) 